\title{
THE GUANIDINE BASES IN THE BLOOD OF DOGS WITH EXPERIMENTAL HYPERTENSION PRODUCED BY CONSTRICTION OF THE RENAL ARTERIES
}

\author{
BY CHARLES G. CHILD \\ (From the Department of Experimental Surgery, of the New York Hospital and Cornell \\ Medical College, New York City)
}

(Received for publication January 20, 1938)

When Goldblatt and coworkers (1) in 1934 first announced that a significant and sustained elevation in arterial blood pressure could be produced in dogs by constriction of the renal arteries they also reported a few experiments in which the level of the guanidine bases in the blood stream of these animals had been followed. Although their preliminary studies indicated that these substances were not involved in either the production or maintenance of this type of experimental hypertension, they suggested that the results were not conclusive and that the group as a whole deserved further study. It is the purpose of this report to record the results of several experiments which have been undertaken in this laboratory in an effort to determine what relationship, if any, these bases bear to this type of hypertension.

That there might be some relationship between the guanidine bases and hyperpiesia is not a particularly new concept. In 1924 Major and Stephenson (2) emphasized that many of these substances produced a marked and prolonged rise in blood pressure. Following Major's initial studies several efforts have been made to demonstrate an increased amount of the guanidine bases in the blood of hypertensive patients (3) as well as in eclampsia (4). That these investigations have been inconclusive is evidenced by the contradictory nature of the reports that have appeared up to the present time. Of further interest are the experiments of Minot and Dodd (5) who report that an accumulation of guanidine bases is present in the blood stream of dogs in which a ricin necrosis has been produced. Therefore, not only because of the normal existence of these substances and their excretion by the kidney, but also because of their relationship to degenerating tissue, it has seemed significant to establish what relationship, if any, they might bear to that type of experimental hypertension which may be produced by constriction of the renal artery.

\section{METHODS}

Male and female dogs weighing between 10 and 12 $\mathrm{kgm}$. have been used throughout the experiments. The daily determinations of blood pressure have been made either by the Van Leersum carotid loop method, or, in several of the shorter experiments, by direct arterial puncture. Constriction of the renal artery has been obtained by either the Goldblatt clamp, or small silver clips designed in this laboratory; complete occlusion of the artery has been accomplished by ligature with heavy silk. The blood urea nitrogen and nonprotein nitrogen have been determined by the usual methods. The level of the guanidine bases has been determined by the colorometric method of Major as modified by Minot and Dodd (5). These chemical studies have been made in all cases on blood withdrawn from the jugular vein at least eighteen hours after the last intake of food. All animals have been fed a normal balanced diet.

The experiments which have been undertaken are given below.

Experiment I. Severe hypertension was produced in two dogs with but a single kidney and that transplanted to the femoral vessels. This was accomplished by constricting the femoral artery with a small silver clip. Both of these animals died, and at autopsy diffuse necrosis of the kidney was found in each instance. The

TABLE I

Experiment I

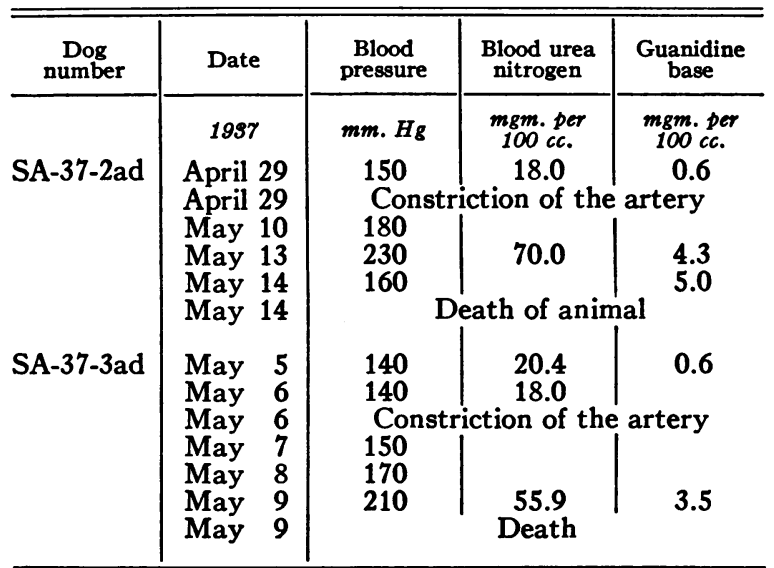


blood pressure, blood urea nitrogen, and guanidine base values are given in Table $I$.

Experiment II. A marked rise in blood pressure was produced in three normal animals by constriction of both renal arteries, and in one dog with a single kidney which had been transplanted to the femoral vessels by constriction of the femoral artery. In all three of these a persistent hypertension was produced. The values are given in Table II.

TABLE II

Experiment II

\begin{tabular}{|c|c|c|c|c|c|}
\hline $\begin{array}{c}\text { Dog } \\
\text { number }\end{array}$ & Date & $\underset{\text { pressure }}{\text { Blood }}$ & $\underset{\substack{\text { Non- } \\
\text { nitrotein }}}{\stackrel{\text { nogen }}{ }}$ & $\begin{array}{c}\text { Blood } \\
\text { urea } \\
\text { nitrogen }\end{array}$ & $\underset{\text { base }}{\text { Guanidine }}$ \\
\hline & 1997 & mm. $\mathrm{Hg}$ & $\begin{array}{l}\text { mgm. per } \\
100 \text { cc. }\end{array}$ & $\begin{array}{c}\text { mgm. per } \\
100 \text { cc. }\end{array}$ & $\begin{array}{l}\text { mgm. per } \\
100 \text { cc. }\end{array}$ \\
\hline \multirow[t]{7}{*}{ SA-37-75 } & $\begin{array}{ll}\text { May } 13 \\
\text { May } 14 \\
\text { May } 14\end{array}$ & $\begin{array}{l}130 \\
145 \\
\text { Constri }\end{array}$ & ction of $b$ & $\begin{array}{l}17.7 \\
\text { oth renal }\end{array}$ & $\begin{array}{c}0.6 \\
\text { arteries }\end{array}$ \\
\hline & May 16 & 160 & & & \\
\hline & May 17 & 130 & & 18.6 & 0.6 \\
\hline & $\begin{array}{ll}\text { May } 24 \\
\text { May } 25\end{array}$ & $\begin{array}{l}130 \\
130\end{array}$ & & 18.6 & 0.8 \\
\hline & May 25 & Furthe & $\begin{array}{r}\text { constric } \\
\text { art }\end{array}$ & $\begin{array}{l}\text { tion of bo } \\
\text { eries }\end{array}$ & th renal \\
\hline & $\begin{array}{l}\text { May } 26 \\
\text { May } 27\end{array}$ & $\begin{array}{l}190 \\
200\end{array}$ & & & \\
\hline & $\begin{array}{l}\text { May } 28 \\
\text { June } 4 \\
\text { June } 14\end{array}$ & $\begin{array}{l}200 \\
210 \\
200\end{array}$ & $\begin{array}{l}46.6 \\
44.1\end{array}$ & $\begin{array}{l}22.8 \\
22.3 \\
16.3\end{array}$ & $\begin{array}{l}0.7 \\
0.8 \\
0.8\end{array}$ \\
\hline \multirow[t]{2}{*}{ SA-37-81 } & April 28 & 160 & & 18.8 & 0.5 \\
\hline & $\begin{array}{lr}\text { April } & 28 \\
\text { May } & 12 \\
\text { May } & 18 \\
\text { May } & 21 \\
\text { May } & 26 \\
\text { June } & 2 \\
\text { July } & 16\end{array}$ & \begin{tabular}{l|} 
Constri \\
240 \\
260 \\
240 \\
230 \\
210 \\
200
\end{tabular} & $\begin{array}{l}53.4 \\
39.9\end{array}$ & \begin{tabular}{|c} 
oth renal \\
34.0 \\
32.1 \\
30.2 \\
32.6 \\
22.3
\end{tabular} & \begin{tabular}{|c} 
arteries \\
2.1 \\
2.5 \\
1.6 \\
1.8 \\
0.8
\end{tabular} \\
\hline \multirow[t]{6}{*}{ SA-37-73 } & May 6 & 130 & & 19.0 & 0.6 \\
\hline & May 6 & Cons & & femoral & artery \\
\hline & May 12 & 230 & & 34.0 & 0.4 \\
\hline & May 21 & $\begin{array}{l}100 \\
180\end{array}$ & & $\begin{array}{l}25.1 \\
24.2\end{array}$ & $\begin{array}{l}0.4 \\
1.5\end{array}$ \\
\hline & May 25 & 170 & & 20.0 & 0.8 \\
\hline & $\begin{array}{ll}\text { June } & 10 \\
\text { June } & 16\end{array}$ & $\begin{array}{l}180 \\
170\end{array}$ & & $\begin{array}{l}18.6 \\
20.9\end{array}$ & $\begin{array}{l}0.9 \\
0.9\end{array}$ \\
\hline
\end{tabular}

Experiment III. Two animals have been studied in which there had been an elevated blood pressure for over six months. As the initiation of the hypertension in these animals antedated these experiments no normal values are available (Table III).

Experiment $I V$. In an attempt to gain a nearer approach to the significance of the guanidine bases four animals were studied in which one renal artery was ligated. In two of these the ligature was removed after a few days in an effort to promote absorption of necrotic renal tissue.

Experiment $V$. As there seemed little doubt but that the values for the guanidine bases paralleled those obtained for the blood urea nitrogen and, when determined, the nonprotein nitrogen, it seemed of significance to con-
TABLE III

Experiment III

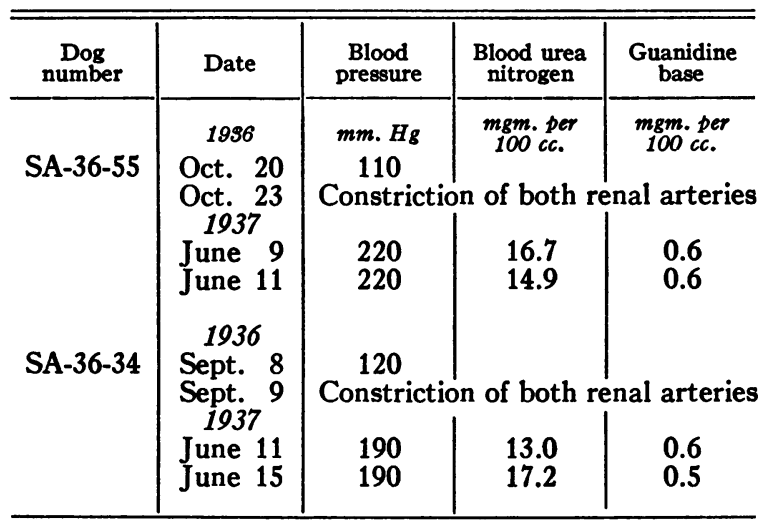

TABLE IV

Experiment IV

\begin{tabular}{|c|c|c|c|c|c|}
\hline $\begin{array}{c}\text { Dog } \\
\text { number }\end{array}$ & Date & $\begin{array}{c}\text { Blood } \\
\text { pressure }\end{array}$ & $\begin{array}{c}\text { Non- } \\
\text { protein } \\
\text { nitrogen }\end{array}$ & $\begin{array}{c}\text { Blood } \\
\text { urea } \\
\text { nitrogen }\end{array}$ & $\begin{array}{c}\text { Guanidine } \\
\text { base }\end{array}$ \\
\hline \multirow{9}{*}{ SA-37-52 } & 1987 & $\mathrm{~mm} . \mathrm{Hg}$ & $\begin{array}{l}\text { mgm. per } \\
100 \mathrm{cc.}\end{array}$ & $\begin{array}{l}\text { mgm. per } \\
100 \mathrm{cc.}\end{array}$ & $\begin{array}{l}\text { mgm. per } \\
100 \text { cc. }\end{array}$ \\
\hline & June 1 & 108 & 33.3 & 17.9 & 0.6 \\
\hline & June 1 & Ligat & Ire of the & left renal & artery \\
\hline & June 3 & 124 & 34.2 & 17.9 & 0.7 \\
\hline & June 4 & 160 & 34.2 & 15.8 & 0.7 \\
\hline & June 5 & 178 & 38.0 & 13.0 & 0.6 \\
\hline & June 7 & 140 & 34.2 & 13.5 & 0.8 \\
\hline & June 7 & & \multicolumn{3}{|c|}{ Removal of ligature } \\
\hline & $\begin{array}{l}\text { June } 8 \\
\text { June } 10\end{array}$ & $\begin{array}{l}122 \\
106\end{array}$ & 27.2 & $\begin{array}{l}12.5 \\
15.8\end{array}$ & $\begin{array}{l}0.7 \\
0.8\end{array}$ \\
\hline \multirow[t]{13}{*}{ SA-37-70 } & $\begin{array}{l}\text { May } 24 \\
\text { May } 25\end{array}$ & $\begin{array}{l}160 \\
160\end{array}$ & & & \\
\hline & $\begin{array}{l}\text { May } 26 \\
\text { May } 26\end{array}$ & Ligat & $\begin{array}{l}36.0 \\
\text { Ire of the }\end{array}$ & $\begin{array}{c}17.7 \\
\text { left renal }\end{array}$ & $\begin{array}{r}0.7 \\
\text { artery }\end{array}$ \\
\hline & May 27 & 180 & 39.9 & 20.0 & 1.9 \\
\hline & May 28 & 180 & 57.0 & 30.7 & 2.1 \\
\hline & May 29 & 195 & 66.0 & 37.7 & 2.2 \\
\hline & May 29 & & \multicolumn{3}{|c|}{ Removal of ligature } \\
\hline & May 30 & 160 & & 16.3 & 2.2 \\
\hline & May 31 & 160 & & 22.3 & 2.1 \\
\hline & June 2 & 160 & 65.1 & 33.0 & 27 \\
\hline & June 3 & 160 & 57.0 & 27.9 & 2.5 \\
\hline & June 4 & 160 & 60.0 & 29.8 & 2.3 \\
\hline & June 8 & 155 & 44.4 & 21.4 & 0.8 \\
\hline & June 14 & & & & \\
\hline \multirow[t]{5}{*}{ SA-37-73 } & June 7 & 106 & \multirow{3}{*}{ re of the } & \multirow{2}{*}{14.4} & 0.6 \\
\hline & June 7 & Ligat & & & artery \\
\hline & June 8 & 102 & & 13.0 & 0.6 \\
\hline & June 9 & 100 & 27.9 & 12.5 & 0.5 \\
\hline & $\begin{array}{l}\text { June } 10 \\
\text { June } 11\end{array}$ & $\begin{array}{l}100 \\
128\end{array}$ & & $\begin{array}{l}25.0 \\
24.6\end{array}$ & $\begin{array}{l}0.5 \\
0.5\end{array}$ \\
\hline \multirow[t]{7}{*}{ SA-37-74 } & June 7 & 98 & \multirow{2}{*}{$\begin{array}{l}36.3 \\
\text { Ire of the }\end{array}$} & 17.7 & 0.7 \\
\hline & June 7 & Ligat & & left renal & artery \\
\hline & June 8 & 132 & 48.0 & 20.5 & 0.7 \\
\hline & June 9 & 120 & 37.5 & 15.3 & 0.8 \\
\hline & June 10 & 134 & & 19.5 & 0.7 \\
\hline & June 14 & 110 & & 15.6 & 0.7 \\
\hline & June 16 & 116 & & 16.3 & 0.7 \\
\hline
\end{tabular}


trol these experiments by performing similar determinations on bilaterally nephrectomized dogs.

\section{DISCUSSION}

In analyzing the above results as they appear under their various headings, one fact of particular significance is evident, that in general the rise in guanidine bases parallels the nitrogen retention in the blood stream irrespective of the blood pressure. Dogs SA-37-61 and SA-37-77 in which bilateral nephrectomy was undertaken show a rise in guanidine bases comparable to Dogs SA-37-2ad and SA-37-3ad which died following restriction of the renal blood supply. No

TABLE V

Experiment $V$

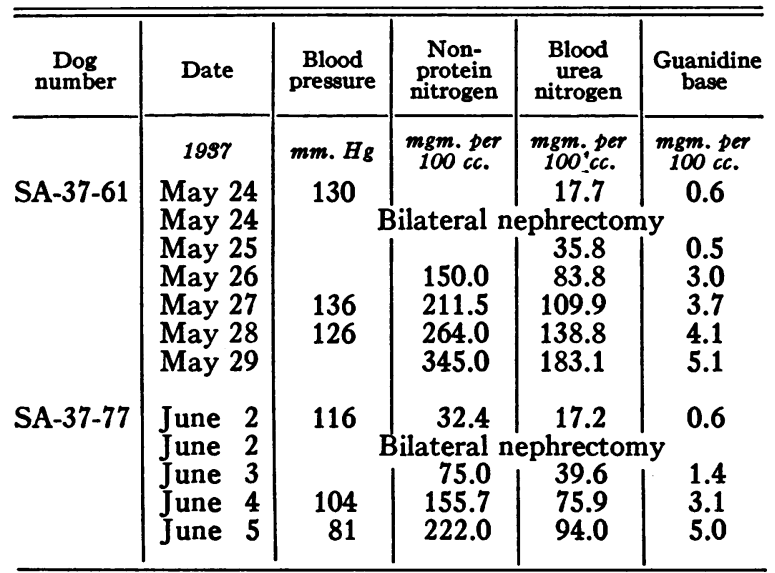

hypertension appeared in the nephrectomized animals, while the rise was marked in those in which the femoral arteries were constricted. The question may be brought up whether or not these latter two animals merely died from renal insufficiency. Undoubtedly this played a part, but their death was associated with a marked degree of hypertension, a phenomenon not shown by animals dying in total renal insufficiency such as is demonstrated by nephrectomized dogs.

In the experiments in which an acute rise in blood pressure was produced by constriction of the renal artery, and following which the animals survived, Dog SA-37-75 showed an insignificant transient rise in blood pressure following the first constriction without any change in the blood urea nitrogen, the nonprotein nitrogen, or the guanidine bases. Following the further constriction of the arteries, there was a marked rise in blood pressure accompanied by but slight rise in nonprotein nitrogen, blood urea nitrogen, and guanidine bases. In Dog SA-37-81, however, there was a marked rise in blood pressure, moderate rise in nonprotein nitrogen, blood urea nitrogen, and guanidine bases. These two experiments are compatible, within the limits of experimental error, with a conclusion that any rise in guanidine bases is related merely to the degree of nitrogen retention. In Dog SA-37-73 a contradiction is found to this conception for here is an animal in which an elevated blood urea nitrogen is associated with an increased blood pressure while the guanidine bases are normal. In fact, as the blood pressure and blood urea nitrogen fall, there is even a slight rise in guanidine bases. This animal cannot be justly compared with the first two for the experimental situations differ somewhat; this animal possessed but one kidney and that transplanted. Although this theoretically should be of little significance, still it vitiates comparison.

When the two animals with hypertension of long standing, six and eight months respectively, are compared, the blood urea nitrogen and nonprotein nitrogen and guanidine bases are found to be normal, yet both of these animals show elevations in blood pressure far above their normal level.

In the last group in which a correlation between the absorption of necrotic renal tissue, hypertension, and the guanidine bases was attempted, the results are contradictory. In three, Dogs SA37-52, SA-37-70, and SA-37-74, ligature of the renal artery was followed within twenty-four hours by a rise in blood pressure. In Dog SA37-73 no rise appeared, at least not until late in the course of the experiment. In Dogs SA37-52, SA-37-73, and SA-37-74 there were no significant changes in the blood urea nitrogen, nonprotein nitrogen, or guanidine bases. But in Dog SA-37-70 all of these three factors showed a moderate transient rise. No explanation can be given for this other than to suggest that this animal experienced some difficulty in rapidly accommodating itself to the functional removal of one kidney. It will be noticed that these values returned to normal after thirteen days.

In Dogs SA-37-52 and SA-37-70, the ligature was removed from the artery in an attempt to promote a more rapid absorption of necrotic renal 
tissue. No unusual results of this procedure were noted, as reflected in either the blood pressure, the blood urea nitrogen or the guanidine bases.

\section{CONCLUSIONS}

1. The guanidine bases in the peripheral blood stream rise following bilateral nephrectomy.

2. The guanidine bases rise in the peripheral blood stream in animals in which both arteries are partially constricted. This rise is roughly proportional to the nitrogen retention, and apparently depends on the degree of renal damage occasioned by constriction of the artery.

3. The guanidine bases do not rise in the blood stream following ligature of one renal artery, unless a nitrogen retention appears, which in turn is apparently dependent upon the occasional inability of the normal kidney to take over immediately the function of the opposite organ.

4. No etiological relationship could be demonstrated between this type of experimental hypertension and the appearance of the guanidine bases in the blood stream occasioned either by partial constriction of one or both renal arteries, or by ligature of one renal artery.

\section{BIBLIOGRAPHY}

1. Goldblatt, H., Lynch, J., Hanzal, R. F., and Summerville, W. W., Studies on experimental hypertension. I. The production of persistent elevation of systolic blood pressure by means of renal ischemia. J. Exper. Med., 1934, 59, 347.

2. Major, R. H., and Stephenson, W., The effect of methyl guanidine on the blood pressure. Johns Hopkins Hosp. Bulletin, 1924, 35, 140.

Further observations on the elevation in blood pressure produced by guanidine compounds. Ibid., 1924, 35, 186.

3. Major, R. H., and Weber, C. J., The probable presence of increased amounts of guanidine in the blood of patients with arterial hypertension. Johns Hopkins Hosp. Bull., 1927, 40, 85.

The possible increase of guanidine in the blood of certain persons with hypertension. Arch. Int. Med., 1927, 40, 891.

4. Stander, H. J., Blood guanidine base concentration in eclampsia. Am. J. Obst. and Gynec., 1932, 23, 373.

5. Minot, A. S., and Dodd, K., Guanidine intoxication. A complicating factor in certain clinical conditions in children. Am. J. Dis. Child., 1933, 46, 522. 